Article

\title{
Analysis of the Supercritical Water Gasification of Cellulose in a Continuous System Using Short Residence Times
}

\author{
M. Belen García-Jarana ${ }^{1, * \mathbb{C}}$, Juan R. Portela ${ }^{1}$, Jezabel Sánchez-Oneto ${ }^{1}$, \\ Enrique J. Martinez de la Ossa ${ }^{1}$ (D) and Bushra Al-Duri ${ }^{2}$ \\ 1 Department of Chemical Engineering and Food Technology, University of Cadiz, Agro Food International \\ Excellence Campus CeiA3, 11510 Puerto Real, Spain; juanramon.portela@uca.es (J.R.P.); \\ jezabel.sanchez@uca.es (J.S.-O.); enrique.martinezdelaossa@uca.es (E.M.d.1.O.) \\ 2 Department of Chemical Engineering, School of Chemical Engineering, University of Birmingham, \\ Edgbaston, Birmingham B15 2TT, UK; b.al-duri@bham.ac.uk \\ * Correspondence: belen.garcia@uca.es
}

Received: 30 June 2020; Accepted: 24 July 2020; Published: 28 July 2020

\begin{abstract}
Supercritical Water Gasification (SCWG) has the capacity to generate fuel gas effluent from wet biomass without previously having to dry the biomass. However, substantial efforts are still required to make it a feasible and competitive technology for hydrogen production. Biomass contains cellulose, hemicellulose and lignin, so it is essential to understand their behavior in high-pressure systems in order to optimize hydrogen production. As the main component of biomass, cellulose has been extensively studied, and its decomposition has been carried out at both subcritical and supercritical conditions. Most previous works of this model compound were carried out in batch reactors, where reaction times normally take place in a few minutes. However, the present study demonstrates that gasification reactions can achieve efficiency levels of up to $100 \%$ in less than ten seconds. The effect of temperature $\left(450-560{ }^{\circ} \mathrm{C}\right)$, the amount of oxidant (from no addition of oxidant to an excess over stoichiometric of $10 \%, \mathrm{n}=1.1)$, the initial concentration of organic matter $(0.25-2 \mathrm{wt}$. $\%)$ and the addition of a catalyst on the SCWG of cellulose in a continuous tubular reactor at short residence times (from 6 to $10 \mathrm{~s}$ ) have been studied in this work. Hydrogen yields close to 100\% in the gas phase were obtained when operating under optimal conditions. Moreover, a validation of the experimental data has been conducted based on the theoretical data obtained from its kinetics.
\end{abstract}

Keywords: supercritical water gasification; cellulose; hydrogen; continuous reactor; process parameters; kinetics

\section{Introduction}

Supercritical water gasification (SCWG) is a promising technology through which renewable hydrogen can be obtained from biomass. This process presents some advantages in comparison with other conventional processes, since electricity can be obtained when the gaseous product is directly burnt in engines or turbines. Moreover, traditional gasification technologies generally produce a low-quality gas that requires costly purification procedures in order to meet essential quality standards [1]. Furthermore, biomass needs to be previously dried and this procedure represents additional running costs [2]. This is why we consider that SCWG appears to be a feasible solution to these issues. In SCWG processes, supercritical water (i.e., temperature and pressure higher than $374{ }^{\circ} \mathrm{C}$ and 221 bar, respectively), acts as both a solvent for organic materials and a reactant, which means that a previous biomass drying procedure is not required. Furthermore, compared to conventional gasification processes, SCWG requires lower temperature levels to produce hydrogen. In fact, SCWG 
processes need a temperature over $600{ }^{\circ} \mathrm{C}$ and pressure level above water critical point, plus the addition of a small amount of oxygen to mainly produce hydrogen. Moreover, supercritical water has the capacity to dissolve the organic components that are found in biomass from plants, such as cellulose or lignin. This favors the hydrolysis reactions that degrade the organic polymeric structures in contrast with the pyrolysis reactions that are typical in conventional gasification techniques. In the hydrolysis reactions that take place in SCWG processes, the products are solved in hot compressed water. Thus, the formation of char and tar that takes place in pyrolysis reactions is prevented. Nevertheless, SCWG of biomass is a complex process where a number of competitive reactions (hydrolysis, water-gas shift, oxidation, methanation, etc.) take place to some extent, depending on the reaction specific conditions [3]. The complete procedure of a SCWG process comprises a complex pattern of pathways, but the reactions involved could be explained in a simplified manner as follows:

Oxidation reactions $[4,5]$ :

$$
\begin{gathered}
\mathrm{H}_{2}+1 / 2 \mathrm{O}_{2} \rightarrow \mathrm{H}_{2} \mathrm{O} ; \quad \Delta \mathrm{H}^{\mathrm{o}} 298=-242 \mathrm{~kJ} / \mathrm{mol} \\
\mathrm{CO}+1 / 2 \mathrm{O}_{2} \rightarrow \mathrm{CO}_{2} ; \quad \Delta \mathrm{H}^{\mathrm{o}} 298=-283 \mathrm{~kJ} / \mathrm{mol} \\
\mathrm{CH}_{4}+2 \mathrm{O}_{2} \rightarrow \mathrm{CO}_{2}+2 \mathrm{H}_{2} \mathrm{O} \quad \Delta \mathrm{H}^{\mathrm{o}} 298=-802 \mathrm{~kJ} / \mathrm{mol}
\end{gathered}
$$

Methanation reactions [6]:

$$
\begin{gathered}
\mathrm{CO}+3 \mathrm{H}_{2} \leftrightarrow \mathrm{CH}_{4}+\mathrm{H}_{2} \mathrm{O} \quad \Delta \mathrm{H}^{\mathrm{o}} 298=-206.17 \mathrm{~kJ} / \mathrm{mol} \\
\mathrm{CO}_{2}+4 \mathrm{H}_{2} \leftrightarrow \mathrm{CH}_{4}+2 \mathrm{H}_{2} \mathrm{O} \quad \Delta \mathrm{H}^{\mathrm{o}} 298=-165.01 \mathrm{~kJ} / \mathrm{mol}
\end{gathered}
$$

Hydrolysis reaction:

$$
\mathrm{C}_{\mathrm{n}} \mathrm{H}_{\mathrm{m}} \mathrm{O}_{\mathrm{y}}+(\mathrm{n}-\mathrm{y}) \mathrm{H}_{2} \mathrm{O} \rightarrow \mathrm{nCO}+(\mathrm{n}-\mathrm{y}+\mathrm{m} / 2) \mathrm{H}_{2} \Delta \mathrm{H}=\text { endothermic, hydrocarbon dependent }
$$

Water-gas shift reactions [6]:

$$
\mathrm{CO}+\mathrm{H}_{2} \mathrm{O} \leftrightarrow \mathrm{CO}_{2}+\mathrm{H}_{2} \quad \Delta \mathrm{H}^{\mathrm{o}} 298=-41.15 \mathrm{~kJ} / \mathrm{mol}
$$

The high water content triggers a water-gas-shift reaction $\left(\mathrm{CO}+\mathrm{H}_{2} \mathrm{O} \leftrightarrow \mathrm{CO}_{2}+\mathrm{H}_{2}\right)$ when gas products are formed from the intermediates. Hence, $\mathrm{a}_{2}$-rich gas is obtained with a low $\mathrm{CO}$ yield. Hydrogen is a clean fuel with a higher energy content $(120 \mathrm{MJ} / \mathrm{kg})$ than conventional fuels [7]. Furthermore, the gas obtained from SCWG processes comes out at high pressure levels, which often represents an additional benefit towards its subsequent use [8].

The above-mentioned benefits of SCWG have made it an attractive and frequent object of study over the last two decades. Some of those research works have focused either on cellulose, hemicellulose, lignin, glucose and fructose as model compounds [9-13] or on real biomass such as straw, sawdust, cornstarch, starch and potato waste [14], vinasses [15], sewage sludge [16] or oil mill wastewater as feedstock [17].

SCWG is carried out with no addition of oxidant or with a small amount of dissolved oxygen. Oxidants may be added for two main purposes, namely, to favor the initial breakdown of refractory molecules and to increase the temperature thanks to the exothermic oxidation reactions that take place. Biomass supercritical water gasification is an endothermic reaction, and for this reason, some studies add a small amount of oxidant to favor the energy balance of the process. In partial oxidative gasification processes, heat is generated initially from the oxidation reaction, that heats up the reaction medium. This kind of internal heating method improves gasification efficiency by eluding the heat resistance that is present in external heating procedures [18-20]. Besides, the presence of a small amount of oxidant may contribute to a further gasification of some of the reactants, or some intermediate products may be obtained during the process (for instance, complex-structure compounds such as 
phenols). Such intermediate products might not be fully gasified in the absence of an oxidant that starts off the breaking of some of the molecule bonds [21]. For this reason, hydrogen peroxide is often used as a source of free radicals that help to decompose the phenolic compounds [22]. All in all, gasification efficiency is improved thanks to a reduction in the activation energy required to start the reaction process [23,24]. For example, General Atomic is a company that has set up a demonstrative partial oxidative gasification plant for the production of hydrogen and intends to build an industrial-scale waste treatment plant based on this technology $[25,26]$. Nevertheless, the number of running plants that produce hydrogen from biomass by means of a continuous flow supercritical reactor operating on water partial oxidative gasification principles is still rather short.

Lignocellulosic biomass typical content includes 30-60\% cellulose, $20-40 \%$ hemicellulose and 15-25\% lignin [25]. Since diverse groups of compounds are produced from that cellulose, hemicellulose or lignin, it is necessary to study the behavior of their intermediates and their degradation or reformation routes into gases. Hence, in order to understand the behavior, mechanisms and the breakdown rates of complex lignocellulosic biomass under supercritical conditions, it is necessary to deepen into the development of SCWG processes when applied to their model compounds, such as cellulose, glucose, glycerol, lignin or phenolic compounds [27]. Many researchers have studied the supercritical water gasification of particular biomass types [28-30] and their model compounds [31-33] to explain such behavior and mechanisms in order to enhance the process efficiency.

The production or large amounts of $\mathrm{H}_{2}$ through the SCWG of biomass requires high temperature and pressure levels. For this reason, the effect of different catalysts such as alkali, transitional metals and activated carbon have been studied to reduce the operating conditions and improve hydrogen selectivity [34]. Moreover, the presence of a catalyst may reduce tar and char formation. Many authors have achieved highly efficient gasification levels using alkali metal catalysts such as $\mathrm{Na}_{2} \mathrm{CO}_{3}, \mathrm{KHCO}_{3}$, $\mathrm{K}_{2} \mathrm{CO}_{3}, \mathrm{KOH}$ and $\mathrm{NaOH}$. Alkali metal catalysts promote water-gas shift reaction and enhance $\mathrm{H}_{2}$ yields [35]. Garcia-Jarana et al. [15] showed that the addition of $\mathrm{KOH}$ increases the production of $\mathrm{H}_{2}$ through the supercritical gasification of industrial wastewaters such as vinasses or cutting oils. Ferreira-Pinto et al. [36] studied the effect of $\mathrm{KOH}, \mathrm{NaOH}$ and $\mathrm{Na}_{2} \mathrm{CO}_{3}$ used as catalyst on the SCWG of lactose and whey. The production of $\mathrm{H}_{2}$ went up from $0.41 \mathrm{~mol} \mathrm{H}_{2} / \mathrm{mol}$ lactose without a catalyst to $4.01 \mathrm{~mol} \mathrm{H}_{2} / \mathrm{mol}$ lactose in presence of $0.1 \mathrm{wt} \%$ of $\mathrm{Na}_{2} \mathrm{CO}_{3}$ at $225 \mathrm{bar}, 550{ }^{\circ} \mathrm{C}$, feed of $2.5 \mathrm{wt} \%$ in a continuous system at a feed flowrate of $5 \mathrm{~g} / \mathrm{min}$. Also, the production of $\mathrm{H}_{2}$ by the SCWG of glucose and other biomasses in a batch reactor, at $450{ }^{\circ} \mathrm{C}$ and 340 bar, increased by $80 \%$ when $\mathrm{NaOH}$ was used as the catalyst [37]. Given these positive results, this study comprises a number of experiments where the effect of adding $0.1 \mathrm{wt} \%$ of $\mathrm{KOH}$ to a SCWG process at $535^{\circ} \mathrm{C}$ has been determined.

SCWG is a promising technology towards the conversion of waste biomass into fuels. However, the application of this process at an industrial scale has some limitations that require more research and development to be overcome. In this regard, significant progress has been made thanks to the research studies that have been conducted at VERENA pilot plant in Germany and at the Japanese plant in Hiroshima University. However, reduced size laboratory reactors, mainly of the batch type, have been used for most of the experimental studies on SCWG that have been completed so far. Only a few researchers have had the opportunity to carry out SCWG experiments using continuous flow tubular reactors with short residence times or continuous stirred tank reactors [38-40]. Since a continuous flow reactor has been used in the present study, extremely short residence times have been tested. Thus, on the one hand, the experimental conditions were closer to those found at industrial scale and, on the other hand, some of the main problems or limitations associated to batch reactors could be avoided (reduced sample volumes and difficulties to collect solid, liquid and gas phases, side-effects from long preheating times, etc.), as described by Casademont et al. [39]. Such limitations enlighten how important it is to broaden our knowledge on kinetic parameters and a solid validation with experimental data that contribute to improve the design of the reactors and to better predict the distribution of the products to be obtained. Despite its relevance, only a limited number of kinetic 
models have been reported in the literature. Moreover, this limited information is available on the global kinetics of SCWG [41].

The aim of the present work is to dig into the SCWG processing of cellulose, a biomass model compound, by means of water at supercritical conditions in a continuous reactor and with short residence times. Most previous works on the SCWG of this model compound were carried out in batch reactors and at temperatures below $500{ }^{\circ} \mathrm{C}$. Moreover, higher residence times are used in those previous studies (of the order of minutes at least). This study should cast some light on the effect of temperature and concentration rates on the SCWG of cellulose with regards to an improved hydrogen production with residence times of a few seconds. The experimental tests have been carried out at temperatures ranging from 450 to $560^{\circ} \mathrm{C}$, the amount of oxidant ranged from no addition of oxidant to an excess over stoichiometric oxygen of $10 \%$ (oxygen coefficient, $n=1.1$ ), the initial concentration of organic matter ranged 0.25 and $2 \mathrm{wt} \%$ and, in some cases, $0.1 \mathrm{wt} \%$ of $\mathrm{KOH}$ was added as the catalyst. Moreover, a comparison study of experimental against theoretical data has been completed.

\section{Materials and Methods}

\subsection{Equipment}

The supercritical water gasification experiments were carried out in a laboratory scale continuous-flow system. Figure 1 is a simplified diagram of the experimental set up. All wetted parts, including the pumps and the back-pressure regulator, were made of stainless steel 316 . The reactor was built using a $12 \mathrm{~m}$ long 1/16 in.-o.d. pipe of $3.07 \mathrm{~mL}$ total inner volume. For those experiments where an oxidant was added, the oxidant feed stream was prepared by dissolving the corresponding amount of hydrogen peroxide into deionized water inside a feed tank. A cellulose aqueous solution was elaborated in another feed tank. The two feed streams were pressurized in two different lines by means of two HPLC pumps and then preheated separately. After the preheating step, the two lines were mixed at the reactor inlet. The whole arrangement is located inside an electric heating furnace. The exiting effluent was rapidly cooled by means of a counter current heat exchanger and the pressure was subsequently reduced using a back-pressure regulator. The product stream was then separated into its liquid and vapor phases. The liquid and gas flow rates were measured and three different samples from both phases, liquid and gas, were taken for analysis.

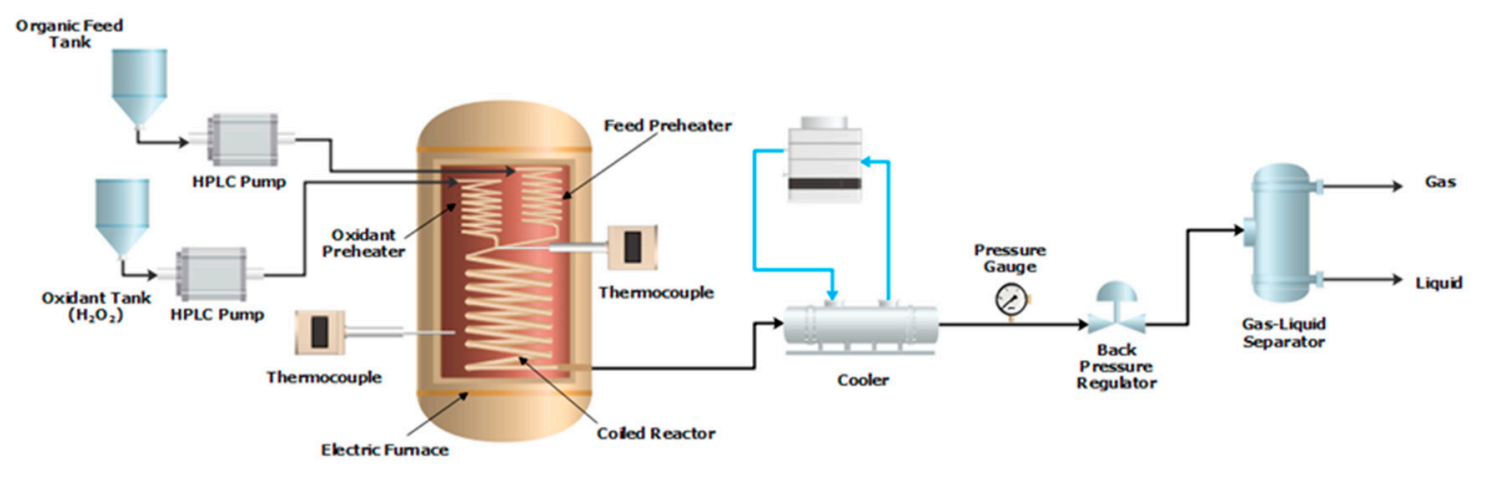

Figure 1. Schematic diagram of the continuous-flow reactor system.

\subsection{Materials and Analytical Methods}

The microcrystalline cellulose powder to be used as biomass model compound for the experiments was purchased from Merck, and hydrogen peroxide (Panreac, 30\% w/v aqueous solution) was used as the source of oxygen. Deionized water was employed to elaborate the feed solutions at the required concentrations.

A gas chromatographer (Agilent 7890A) was used to detect hydrocarbons compounds, $\mathrm{CO}, \mathrm{CO}_{2}$, $\mathrm{N}_{2}$ and $\mathrm{H}_{2}$. The gas chromatograph was configured as a multi column instrument gas analyzer. 
The Thermal Conductivity Detector (TCD2) back signal was used to detect methane, $\mathrm{CO}_{2}, \mathrm{CO}$ and $\mathrm{N}_{2}$. The other auxiliary TCD signals were used just to detect hydrogen. The Total Organic Carbon (TOC) content was determined by means of a TOC analyzer by Shimadzu 5050A.

For the analysis of the volatile compounds, a stir bar sorptive extraction (SBSE) procedure was carried out by means of commercial polydimethylsiloxane $10 \mathrm{~mm}$ length $\times 0.5 \mathrm{~mm}$ film thickness stir bars. A volume of $20 \mathrm{~mL}$ of sample was placed into a $100 \mathrm{ml}$ Erlenmeyer flask that was covered and placed on a magnetic stirrer where the stir bar rotated at $1000 \mathrm{rpm}$ at $25^{\circ} \mathrm{C}$ for $120 \mathrm{~min}$. Then, it was transferred into a glass thermal desorption tube and the thermal desorption procedure was conducted. The equipment used for the thermal desorption of the coated stir bars was connected to a CIS-4 programmed-temperature vaporization (PTV) injector through a heated transfer line. The PTV was installed in an Agilent 6890 GC-5973N MS unit. The PTV system was programmed for analysis by gas chromatography-mass spectrometry (GC-MS).

\section{Results and Discussion}

\subsection{Effects of the Operating Conditions on the SCWG of Cellulose}

Table 1 shows the operating conditions and the reactor types employed in different studies on cellulose SCWG. As can be seen, all experiments were carried out at batch reactors and residence times of minutes.

Table 1. Experimental studies of supercritical water gasification (SCWG) process using cellulose.

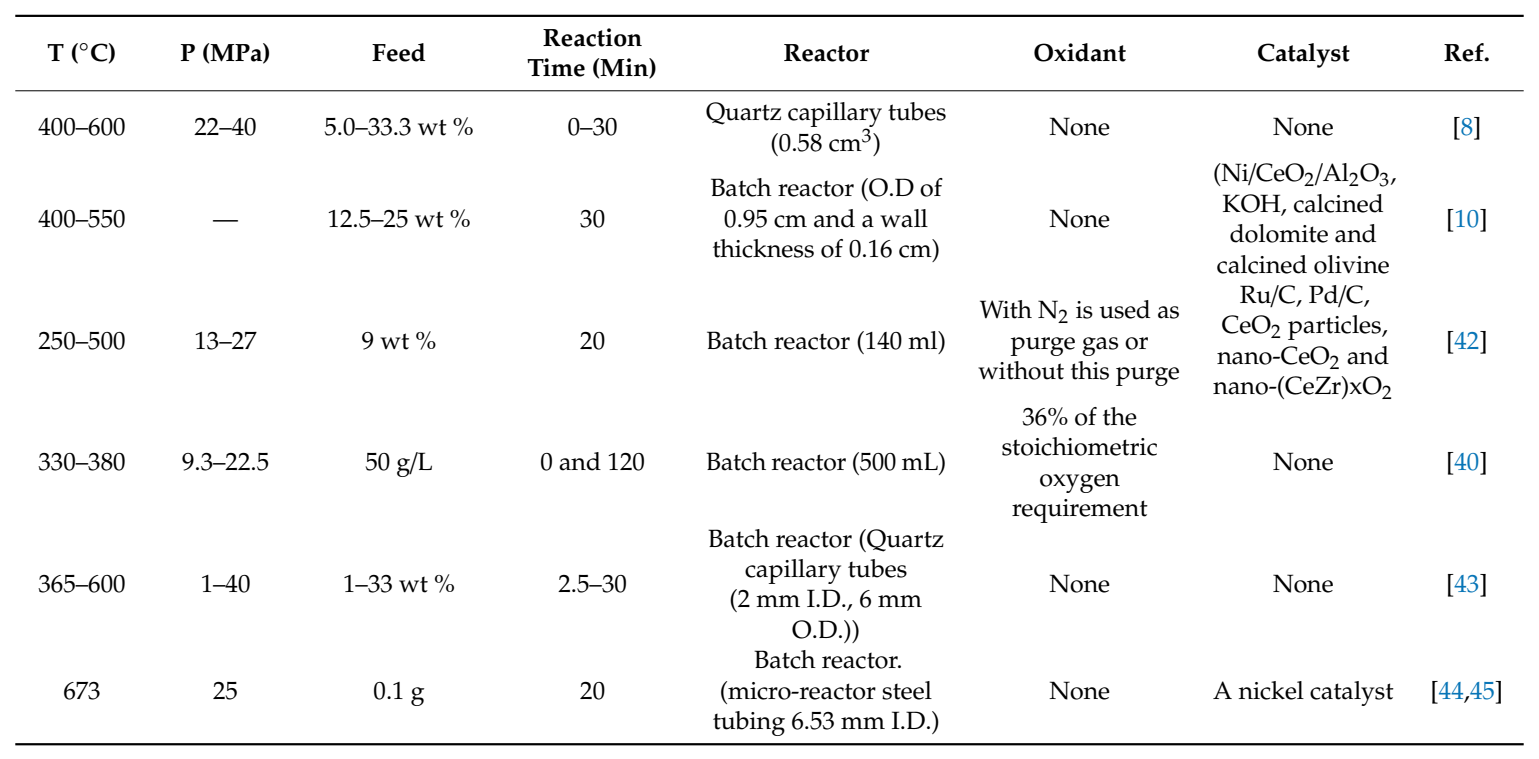

In the present study, different experiments were carried out in order to determine how different operating conditions had an effect on the process. Since SCWG is a complex reaction process, each individual gas yield (mmol/g of feedstock) was determined as the number of moles of each gas with respect to the initial amount of feed. All the experiments were carried out using three different residence times (6-10 s). Three experiments were made in duplicate, showing a good reproducibility. Moreover, multiple injections were made for all samples to establish the reproducibility of the results. The accuracy of those measurements was within $\pm 2 \%$. The results from all the experiments are presented in Table 2. The hydrogen gasification efficiency percentage indicates the amount of hydrogen produced based on the hydrogen that could theoretically be obtained from the initial cellulose feed if a total gasification was achieved based on global gasification reaction (Equation (8)) [46]. As mentioned for Equation (9) [46], the total gasification amount would be $0.1482 \mathrm{~g} \mathrm{H}_{2} / \mathrm{g}$ cellulose. 
Table 2. Summary of the operating conditions and results from the cellulose SCWG experiments.

\begin{tabular}{|c|c|c|c|c|c|c|c|c|c|c|}
\hline $\mathrm{T}\left({ }^{\circ} \mathrm{C}\right)$ & $\begin{array}{l}\text { [Cellulose] } \\
\quad(\mathrm{g} / \mathrm{L})\end{array}$ & $\begin{array}{c}\text { Oxygen } \\
\text { Coef. (n) }{ }^{1}\end{array}$ & Catalyst & $\begin{array}{l}\text { Residence } \\
\text { Time (s) }\end{array}$ & $\begin{array}{c}\mathrm{mmol} \\
\mathrm{H}_{2} / \mathrm{g} \\
\text { Cellulose }\end{array}$ & $\begin{array}{c}\mathrm{mmol} \mathrm{CH}_{4} / \mathrm{g} \\
\text { Cellulose }\end{array}$ & $\begin{array}{c}\mathrm{mmol} \\
\mathrm{CO}_{2} / \mathrm{g} \\
\text { Cellulose }\end{array}$ & $\begin{array}{c}\text { mmol } \\
\mathrm{CO} / \mathrm{g} \\
\text { Cellulose }\end{array}$ & $\begin{array}{c}\text { LHV } \\
\left(\mathrm{kJ} / \mathrm{Nm}^{3}\right)\end{array}$ & $\begin{array}{c}\text { HGE } \\
(\%)\end{array}$ \\
\hline 450 & 0.3 & 0.4 & - & 6 & 11.02 & 0 & 0.18 & 0 & 1189.4 & 14.88 \\
\hline 450 & 0.3 & 0.4 & - & 8 & 10.05 & 0 & 0.12 & 0 & 1084.4 & 13.56 \\
\hline 450 & 0.3 & 0.4 & - & 10 & 9.15 & 0 & 0.11 & 0 & 992.5 & 12.83 \\
\hline 535 & 0.3 & 0.4 & - & 6 & 28.42 & 0 & 0.004 & 0 & 3068.1 & 38.37 \\
\hline 535 & 0.3 & 0.4 & - & 8 & 20.04 & 0 & 0.008 & 0 & 2163.5 & 27.06 \\
\hline 535 & 0.3 & 0.4 & - & 10 & 31.57 & 0 & 0.015 & 0 & 3455.1 & 42.62 \\
\hline 560 & 0.3 & 0.4 & - & 6 & 76.08 & 0.44 & 3.96 & 0 & 8371.8 & 102.70 \\
\hline 560 & 0.3 & 0.4 & - & 8 & 46.91 & 0.02 & 0.07 & 0 & 5071.2 & 63.33 \\
\hline 560 & 0.3 & 0.4 & - & 10 & 44.15 & 0.01 & 0.03 & 0 & 4765.9 & 59.61 \\
\hline 535 & 0.3 & 0 & - & 6 & 1.09 & 0 & 0.05 & 0 & 118.4 & 1.48 \\
\hline 535 & 0.3 & 0 & - & 8 & 0.50 & 0 & 0.01 & 0 & 54.28 & 0.68 \\
\hline 535 & 0.3 & 0 & - & 10 & 0.84 & 0 & 0.03 & 0 & 91.12 & 1.14 \\
\hline 535 & 0.3 & 0.2 & - & 6 & 8.13 & 0 & 0.01 & 0 & 877.02 & 10.97 \\
\hline 535 & 0.3 & 0.2 & - & 8 & 6.94 & 0 & 0.01 & 0 & 749.6 & 9.38 \\
\hline 535 & 0.3 & 0.2 & - & 10 & 4.69 & 0 & 0.007 & 0 & 506.6 & 6.34 \\
\hline 535 & 0.3 & 0.5 & - & 6 & 11.38 & 0 & 0.009 & 0.09 & 1239.2 & 15.35 \\
\hline 535 & 0.3 & 0.5 & - & 8 & 8.69 & 0.11 & 0.16 & 0.15 & 997.1 & 11.73 \\
\hline 535 & 0.3 & 0.5 & - & 10 & 8.03 & 0.05 & 0.08 & 0.02 & 888.2 & 10.84 \\
\hline 535 & 0.3 & 1.1 & - & 6 & 0.9 & 0 & 0.004 & 0.09 & 108.3 & 1.22 \\
\hline 535 & 0.3 & 0.8 & - & 8 & 3.05 & 0 & 0.05 & 0 & 329.2 & 4.12 \\
\hline 535 & 0.3 & 0.6 & - & 10 & 6.39 & 0 & 0.02 & 0 & 690.1 & 8.63 \\
\hline 535 & 0.06 & 0.4 & - & 6 & 58.91 & 0 & 0.02 & 0 & 6359.2 & 79.53 \\
\hline 535 & 0.06 & 0.4 & - & 8 & 57.19 & 0 & 0.03 & 0 & 6173.7 & 77.21 \\
\hline 535 & 0.06 & 0.4 & - & 10 & 65.17 & 0 & 0.04 & 0 & 7034.1 & 87.97 \\
\hline 535 & 0.1 & 0.4 & - & 6 & 68.17 & 0.12 & 0.13 & 0 & 7400.2 & 92.02 \\
\hline 535 & 0.1 & 0.4 & - & 8 & 52.13 & 0.01 & 0.02 & 0 & 5627.1 & 70.38 \\
\hline 535 & 0.1 & 0.4 & - & 10 & 42.83 & 0.03 & 0.01 & 0 & 4633.5 & 57.82 \\
\hline 535 & 0.5 & 0.4 & - & 6 & 6.71 & 0 & 0.007 & 0 & 724.2 & 9.06 \\
\hline 535 & 0.5 & 0.4 & - & 8 & 7.87 & 0 & 0.005 & 0 & 849.4 & 10.62 \\
\hline 535 & 0.5 & 0.4 & - & 10 & 7.36 & 0 & 0.004 & 0 & 794.5 & 9.94 \\
\hline 535 & 0.3 & 0.4 & $\mathrm{KOH}$ & 6 & 83.51 & 18.08 & 0.6 & 14.95 & $17,393.8$ & 112.74 \\
\hline 535 & 0.3 & 0.4 & $\mathrm{KOH}$ & 8 & 72.49 & 8.49 & 8.00 & 1.84 & $11,100.9$ & 97.87 \\
\hline 535 & 0.3 & 0.4 & $\mathrm{KOH}$ & 10 & 45.68 & 2.45 & 3.79 & 0.4 & 5858.3 & 61.67 \\
\hline
\end{tabular}

${ }^{1} \mathrm{n}=$ supplied oxygen/stoichiometric oxygen. When the amount of oxygen in the system matches the stoichiometric amount of oxygen that is required to completely oxidize all the cellulose fed into the system, the oxygen coefficient is unity $(\mathrm{n}=1)$.

Global gasification reaction of cellulose:

$$
\mathrm{C}_{6} \mathrm{H}_{10} \mathrm{O}_{5}+7 \mathrm{H}_{2} \mathrm{O} \leftrightarrow 12 \mathrm{H}_{2}+6 \mathrm{CO}_{2}
$$

Hydrogen gasification efficiency:

$$
\operatorname{HGE}(\%)=\left[\left(\frac{\frac{g H_{2}}{g \text { cellulose }}}{\text { Theoretical }\left(\frac{g H_{2} \text { from Eq. } 8}{g \text { cellulose }}\right)}\right)\right] \times 100
$$

Naturally, the percentages that represent gasification efficiency could be over $100 \%$ in some of the experiments. This is because supercritical water acts as a reactant during the SCWG process, and, therefore, the amount of $\mathrm{H}_{2}$ obtained in gaseous phase can be greater than the one fed into the process as a cellulose component. Moreover, a complex pattern of pathways comprises the complete SCWG process. Therefore, slight modifications with the theoretical calculation based on the global reaction can be obtained. While, the Lower Heating Values (LHV) of the gas products were calculated according to Equation (10), as already described Nanda et al. [47], which is based on the molar yields (mmol/g of feedstock) of $\mathrm{H}_{2}, \mathrm{CO}$ and $\mathrm{CH}_{4}$. The analysis of the different effects on the gasification reaction is explained in the sections below.

$$
L H V\left(\frac{\mathrm{kJ}}{\mathrm{Nm}^{3}}\right)=\left[(30 \times \mathrm{CO})+\left(25.7 \times \mathrm{H}_{2}\right)+\left(85.4 \times \mathrm{CH}_{4}\right)\right] \times 4.2
$$


Unlike the results obtained in most of the previous studies on this subject, generally, the gas phase obtained from the experiments in this work is mainly formed by hydrogen. This is probably due to the use of shorter residence times.

\subsubsection{Effects of Temperature on the SCWG of Cellulose}

Figure 2 describes the influence of temperature on the SCWG process when cellulose is used as feed. The experiments were carried out at 250 bar, 0.4 as oxygen coefficient, and a cellulose aqueous solution feed at $0.3 \mathrm{~g} / \mathrm{L}$ concentration was employed. The effect of specific reaction temperatures was studied within the range $450-560^{\circ} \mathrm{C}$ and over three different residence times $(6,8$ and $10 \mathrm{~s})$. The results in terms of $\mathrm{H}_{2}$ yield (\%) are represented in Figure 2. It is well known and, naturally expected, that higher temperatures result in considerably greater hydrogen yields [48]. Nevertheless, it is important to point out that at $560^{\circ} \mathrm{C}$ and with a very short residence time $(6 \mathrm{~s})$, efficiency levels are really close to $100 \%$. The hydrogen obtained through SCWG may come either from the cellulose or from the water. Moreover, although at low temperatures the effect of the residence time is almost negligible, when the temperature goes up it has a much more significant effect on the outcome. Therefore, longer residence times and higher temperatures usually produce greater gas yields since the thermal cracking reactions of the organic compounds are enhanced [48]. Furthermore, the number of the different reactions between the intermediates resulting from such thermal cracking reactions is also increased. Therefore, in general, higher residence times favor the hydrogen generation, and cause increased participation in other reactions when the concentration is high. Therefore, hydrogen gasification efficiency of the process may be reduced from a longer residence time, being more pronounced at higher temperatures. As can be seen from the experiment results included in Table $2, \mathrm{CH}_{4}$ yields appeared at $560{ }^{\circ} \mathrm{C}$, while no $\mathrm{CO}$ is registered at this temperature. This enhanced hydrogen yield with low carbon monoxide formation as temperature is increased has been previously obtained by other authors $[15,17,49,50]$. However, the equilibrium rate of the water-gas shift direct reaction is slow and its equilibrium constant decreases as temperature increases in the reaction medium. The above-mentioned authors observed a fast-type water-gas shift reaction in their studies on glucose gasification by means of supercritical water. Moreover, in the present work, the LHV of gases increased from $1189.4 \mathrm{~kJ} / \mathrm{Nm}^{3}$ at $450{ }^{\circ} \mathrm{C}$ to $8371.8 \mathrm{~kJ} / \mathrm{Nm}^{3}$ at $560{ }^{\circ} \mathrm{C}$ with a residence time of only $6 \mathrm{~s}$. This increment in LHV is due not only to the greater amount of hydrogen in the gas phase obtained at $560^{\circ} \mathrm{C}$, but also to the presence of methane in small quantities. In fact, this LHV is higher than the maximum LHV obtained in a previous study where the SCWG of lactose as model compound was studied [51]. The authors obtained an LHV of $3513 \mathrm{~kJ} / \mathrm{Nm}^{3}$ at $700^{\circ} \mathrm{C}$ and $60 \mathrm{~s}$.

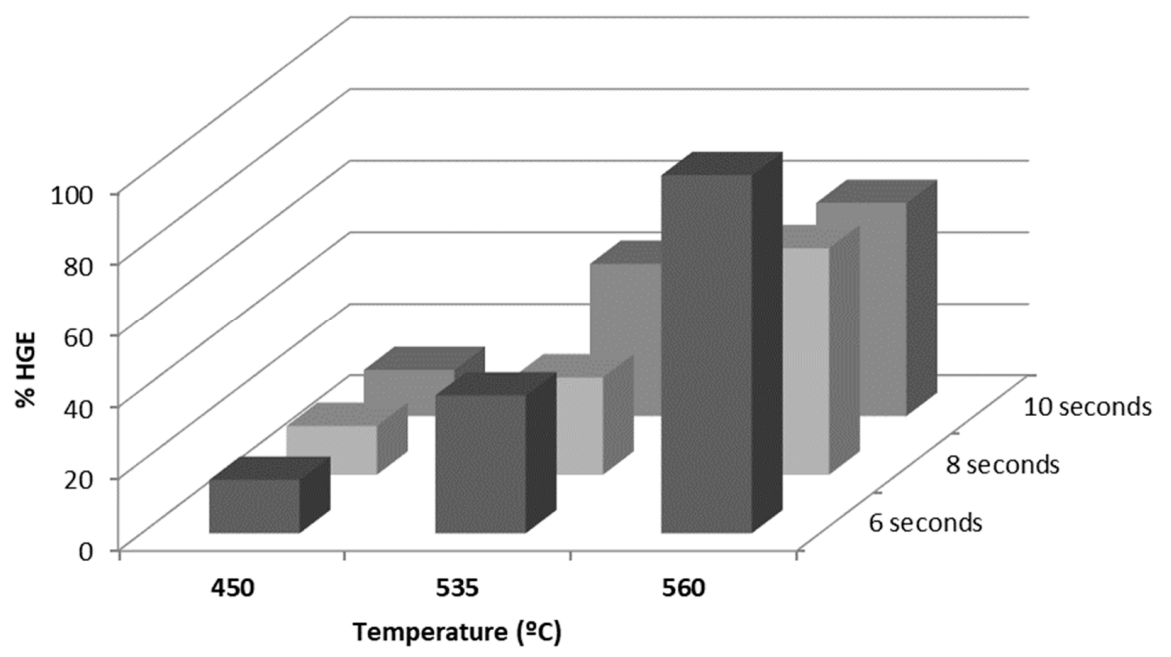

Figure 2. Effect of the reaction temperature on the SCWG of cellulose at 250 bar with an initial concentration of cellulose $=0.3 \mathrm{~g}$ cellulose $/ \mathrm{L}$ and $\mathrm{n}=0.4$. 
Figure 3 shows a chromatogram obtained by GC-MS, where the peaks corresponding to the volatile compounds obtained in the liquid effluent from the SCWG of cellulose at $560{ }^{\circ} \mathrm{C}$ can be seen. According to Figure 4, most of the compounds detected in the liquid effluent obtained at $560{ }^{\circ} \mathrm{C}$, are alcohols (39.9\%) and benzenes (42.8\%). Therefore, under these conditions $\left(560{ }^{\circ} \mathrm{C}\right.$ and a low residence time) most of the initial organic matter is probably removed from the liquid phase and the production of gases is promoted. This is in agreement with the gas yields obtained at $560{ }^{\circ} \mathrm{C}$ (Table 2), where efficiency was close to $100 \%$ at $560{ }^{\circ} \mathrm{C}$ and with $6 \mathrm{~s}$ residence time. To conclude, and according to previous studies with similar results [51,52], gas formation is probably enhanced by some sort of free-radical reaction that takes place under these conditions.

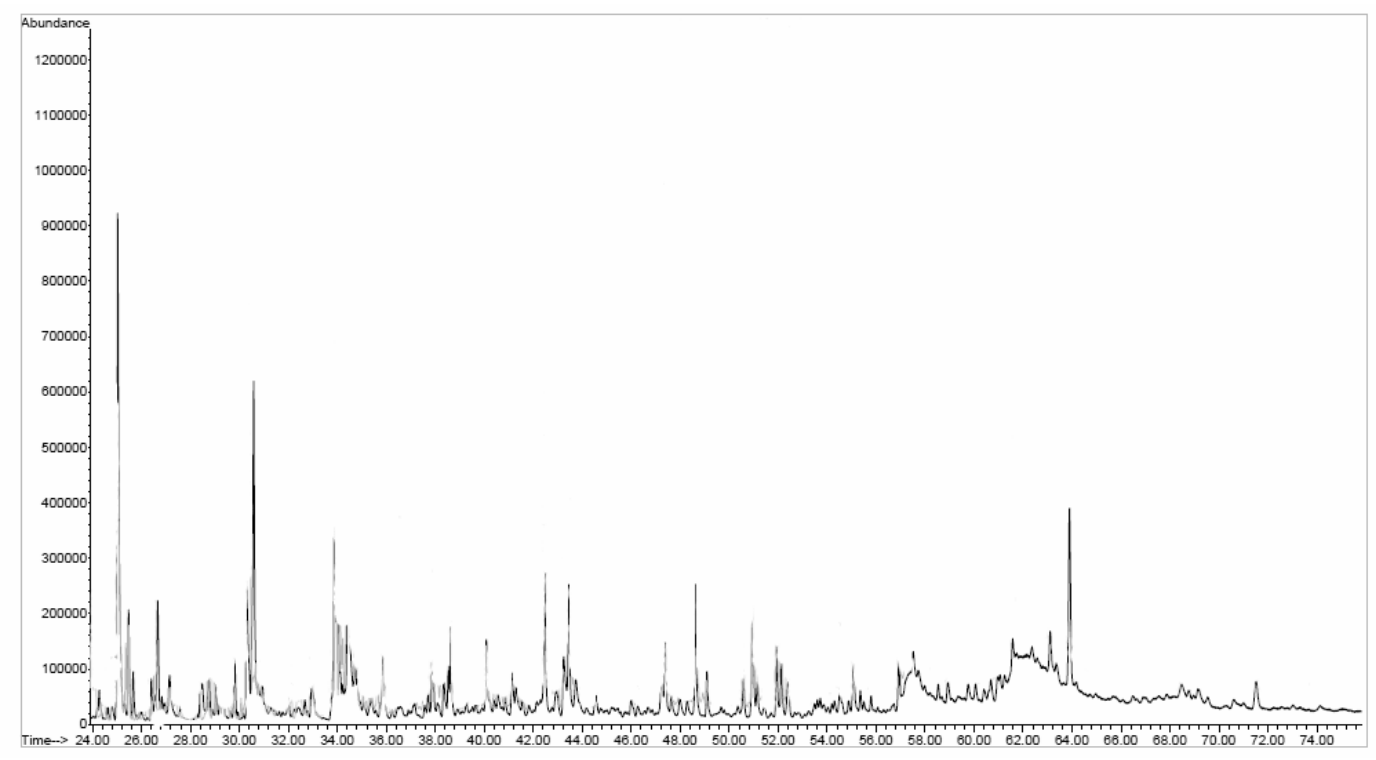

Figure 3. Gas chromatography-mass spectrometry (GC-MS) chromatogram of the effluent obtained from an SCWG process carried out at $560{ }^{\circ} \mathrm{C}, 250 \mathrm{bar}$, with an initial concentration of cellulose $=0.3 \mathrm{~g} / \mathrm{L}$ and $\mathrm{n}=0.4$.

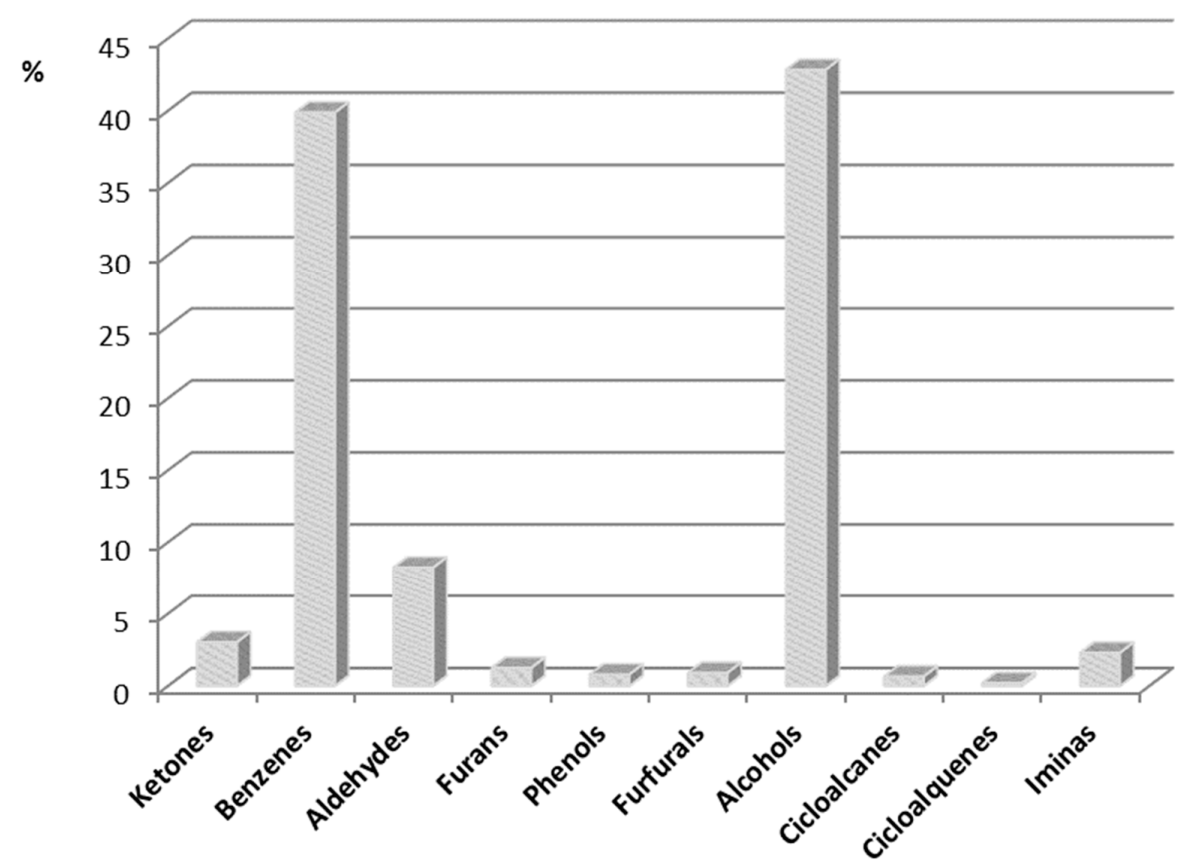

Figure 4. Volatile compounds obtained in the liquid effluent from the SCWG of cellulose at $560{ }^{\circ} \mathrm{C}$. 
On the other hand, although the best results in terms of gasification efficiency have been obtained at $560{ }^{\circ} \mathrm{C}$, the influence of other operating variables has also been determined at $535^{\circ} \mathrm{C}$, where yields are smaller and any improvements in the process may be more evident.

\subsubsection{Influence of Oxygen Coefficient}

The results from the SCWG of cellulose without any oxidant and up to an excess of stoichiometric oxygen, $\mathrm{n}=1.1$, at 250 bar of pressure, and a temperature of $535^{\circ} \mathrm{C}$ with a cellulose initial concentration of $0.3 \mathrm{~g} / \mathrm{L}$ are shown in Figure 5.

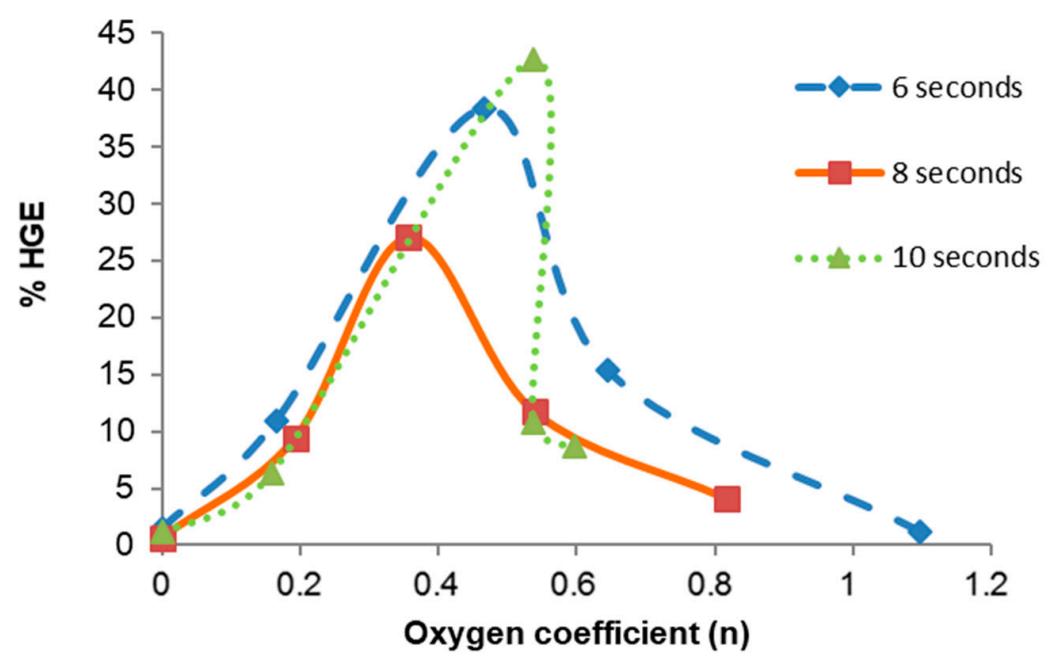

Figure 5. Effects of the oxidant on the SCWG of cellulose at $535{ }^{\circ} \mathrm{C}, 250$ bar and with an initial concentration of cellulose $=0.3 \mathrm{~g}$ cellulose $/ \mathrm{L}$.

As already mentioned in the introduction, when SCWG processes are not added to an oxidant, a significant amount of energy is required to preheat and maintain the desired temperature, since the gasification reactions that take place in SCWG processes are globally endothermic. Therefore, a certain amount of oxidant is added to produce both oxidation and gasification, which in turn reduces the energy requirements of the whole process. It is well known that when cellulose is gasified under oxygen defect ( $n<1$, i.e., a lesser amount of oxygen than the minimum required for a complete oxidation) a considerable amount of $\mathrm{CO}$ and intermediates are generated from the reactions, which later on will produce $\mathrm{H}_{2}$ in the water gas shift reaction [49,53]. It can be seen from Figure 5 that the hydrogen yields increase with an increasing oxygen coefficient until $n=0.5$. From that point, adding more oxidant may have a negative effect, since hydrogen yields would decrease from the moment that the oxidation reactions become predominant over the gasification ones. This effect becomes more evident as residence time is increased. Similar results were obtained in previous studies where glucose was used as feed [25]. As can be seen in Table 2, CO is only obtained from the experiments with $\mathrm{n}>0.5$. Furthermore, an increment of the LHV has been obtained when $n=0.5$.

\subsubsection{Effect of Cellulose Initial Concentration}

Figure 6 shows the hydrogen yields obtained in gas phase depending on the initial concentration of cellulose within the range $0.05-0.55 \mathrm{~g} / \mathrm{L}$. All the experiments were carried out at $250 \mathrm{bar}, 535{ }^{\circ} \mathrm{C}$ and with $\mathrm{n}=0.4$.

It can be seen from Figure 6 that hydrogen yields decrease at high cellulose feed concentration. Some researchers have previously studied the effect that organic matter concentrations have on gas yields and the same trend has been observed [48]. Nanda et al. [51] suggested that it could be attributed to lower reaction rates in water gas shift reaction because of a shorter number of water molecules as the number of organic molecules are increased. Their results are in agreement with the results obtained in 
this work and corroborate their consistency. On the other hand, no significant yield differences have been found between 6 and $10 \mathrm{~s}$ residence times. This probably indicates that minor changes in residence time are not relevant with regards to yields when the temperature remains constant. Moreover, the LHV of the gases obtained was lower when the cellulose feed had a concentration of $0.05 \mathrm{~g} / \mathrm{L}\left(794.5 \mathrm{~kJ} / \mathrm{Nm}^{3}\right)$ than when the concentration was $0.55 \mathrm{~g} / \mathrm{L}\left(7034.1 \mathrm{~kJ} / \mathrm{Nm}^{3}\right)$ (Table 2). These results could suggest that thermal cracking and steam reforming are weaker when high concentrations of cellulose are fed, and this results in a lower LHV [54]. It is, therefore, confirmed that lower cellulose feed concentrations favor larger hydrogen yields ( $92.02 \%$ with $0.08 \mathrm{~g} / \mathrm{L}$ and only $6 \mathrm{~s}$ ). Furthermore, Rodriguez-Correa and Kruse [55], similarly to other research teams, have experimentally and theoretical verified the kinetic and thermodynamic aspects of SCWG. In this sense, due to the Le Chattelier principle, hydrogen yields can be increased when there is a low concentration biomass and, therefore, a greater amount of water is fed into the system. This proportion provides a better thermodynamic equilibrium that favors hydrolysis and water-gas shift reactions. Even though hydrogen yields are in fact reduced when cellulose concentration rates are increased, it is important to highlight that, for the same really short residence times, gasification efficiency can still reach over $50 \%$.

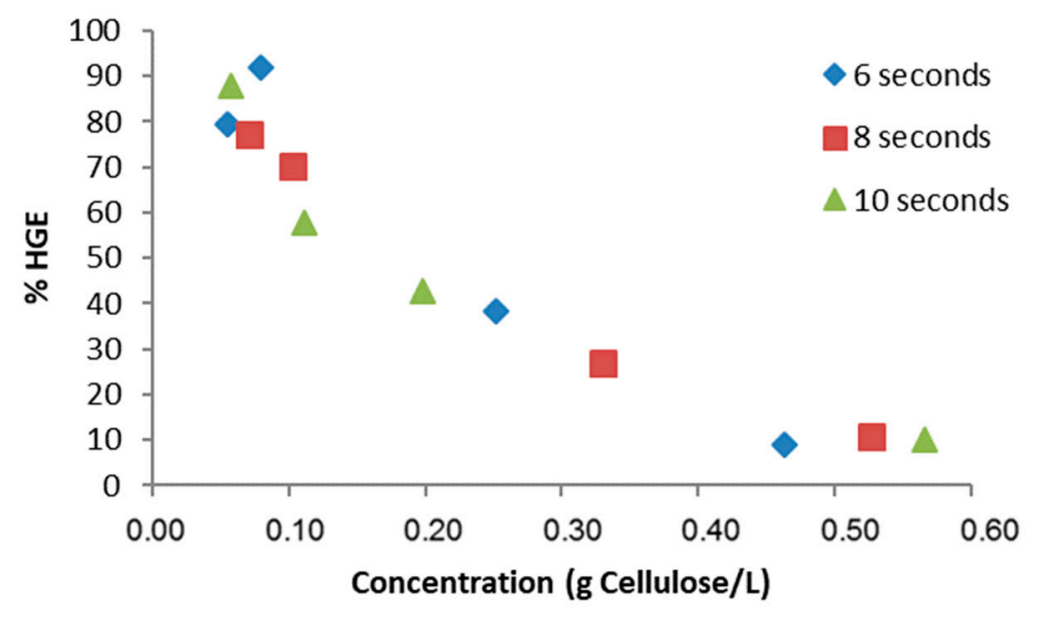

Figure 6. Effect of cellulose initial concentration in SCWG processes at $250 \mathrm{bar}, 535^{\circ} \mathrm{C}$, and with $\mathrm{n}=0.4$.

\subsubsection{Effects of an Alkali Catalyst on the Production Yields}

The use of a catalyst may enhance the $\mathrm{H}_{2}$ yields in the gas effluent from the SCWG system. The presence of catalyst can contribute to prevent some of the undesired reactions and the subsequent production of tar and/or char. Some alkali metal catalysts, mainly $\mathrm{KOH}$ and $\mathrm{NaOH}$, have been demonstrated to have the ability to break $\mathrm{C}-\mathrm{C}$ bonds and promote the water-gas shift reaction, which in turn improves $\mathrm{H}_{2}$ and $\mathrm{CO}_{2}$ yields $[35,47,56,57]$. As can be seen from the results in Table 2, higher $\mathrm{CO}_{2}$ and $\mathrm{CH}_{4}$ yields are obtained in the presence of a catalyst. The effect of a catalyst may be a crucial factor for the success of this study, since very short residence times have been implemented and $\mathrm{H}_{2}$ yields may be substantially boosted thanks to the effect of such catalyst. In order to reduce the number of experiments, the catalyst and concentration to be used have been selected according to the best data found in the literature. Thus, the effect of $\mathrm{KOH}$ at $0.1 \mathrm{wt} \%$ has been studied at $535^{\circ} \mathrm{C}$, 250 bar, $\mathrm{n}=0.4,0.3 \mathrm{~g}$ cellulose/L. Also, a comparison between the experiments carried out with and without catalyst in terms of $\mathrm{H}_{2}$ yield is shown in Figure 7. It can be seen that the presence of a catalyst can be a key point when short residence times are implemented. In fact, there was an increment in the hydrogen yields obtained from all the experiments, and particularly from the 6-s runs, where the presence of the catalyst enhanced hydrogen yields by more than $60 \%$ in comparison to the production obtained when no catalyst was used under the same conditions. Moreover, higher LHV values were obtained using $\mathrm{KOH}$, with maximum yields of $112.74 \%$ and $17393.8 \mathrm{~kJ} / \mathrm{Nm}^{3}$ from 6 -s runs. Similar results have been obtained by Nanda et al. [51] in a study on the SCWG of timothy grass. In that case, 
different homogeneous catalysts were evaluated and an improvement of $\mathrm{H}_{2}$ yields was obtained in all the cases and particularly when $\mathrm{KOH}$ was used.

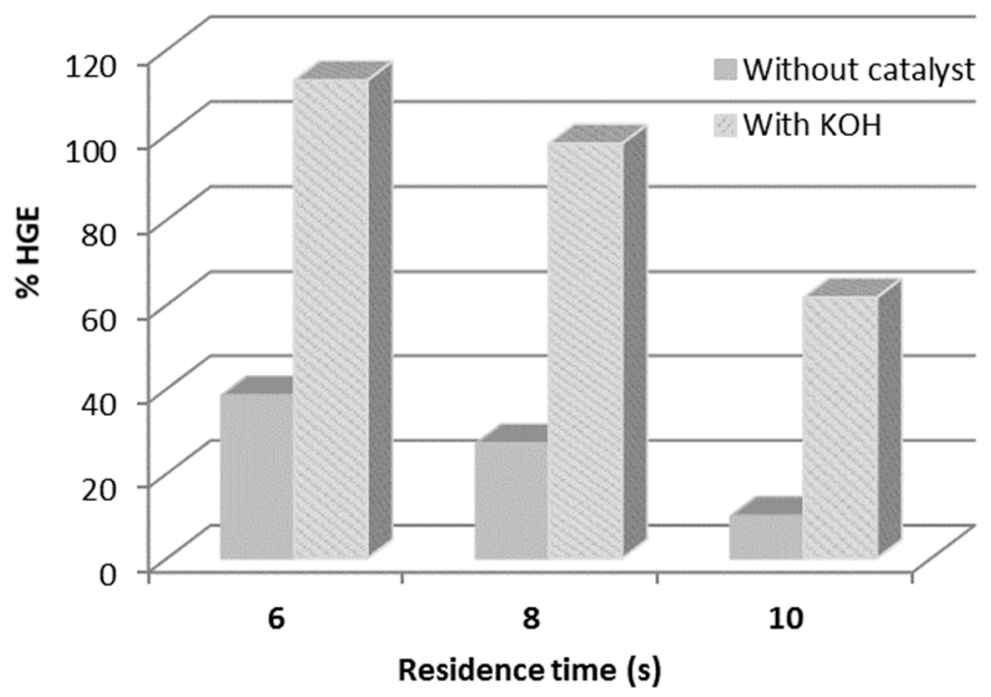

Figure 7. Effects of an alkali catalyst, specifically $\mathrm{KOH}$ at $0.1 \mathrm{wt} \%$, on the SCWG of cellulose at 250 bar, $535^{\circ} \mathrm{C}$, with an initial concentration of cellulose $=0.3 \mathrm{~g} / \mathrm{L}$, and $\mathrm{n}=0.4$.

\subsection{Experimental Data Validation}

It has already been mentioned that, despite the enormous potential of the SCWG processes, its industrial implementation presents some limitations that are still to be overcome. For that reason, the analysis of its kinetic parameters and the subsequent validation with experimental results are essential if successful new reactors are to be designed.

Moreover, as already mentioned in the Introduction, different reactions may take place in SCWG processes, which would make any rigorous study on its kinetics that intends to cover all the possible pathways a task of enormous difficulty. The present study has, therefore, focused on a really simplified kinetic model where the results obtained from our experiments are compared. This should hopefully cast some light on the discussion that has been presented in previous sections with regards to the results obtained in this study.

Lee et al. [32] demonstrated that cellulose is rapidly and completely converted into glucose at temperatures around $400{ }^{\circ} \mathrm{C}$. Hence, in order to simulate the gasification efficiency of the different experiments in this paper, kinetics based on glucose can be used. Tushar et al. [58] found that, although different reaction pathways of glucose decomposition have been proposed, glucose hydrolysis along with water-gas shift are the principal reactions to be taken into account with regards to $\mathrm{H}_{2}$ yields. Lee et al. [32] proposed a simplified model based on a pseudo-first-order kinetics for the production of hydrogen from glucose (Equation (11)).

$$
\mathrm{C}_{6} \mathrm{H}_{12} \mathrm{O}_{6}+6 \mathrm{H}_{2} \mathrm{O} \rightarrow 6 \mathrm{CO}_{2}+12 \mathrm{H}_{2}
$$

The different kinetic parameters proposed in this model were determined and validated with experiments carried out at temperatures ranging from 480 to $750{ }^{\circ} \mathrm{C}$, at 280 bar and with $0.6 \mathrm{M}$ of glucose, no oxidant and a residence time of 10-50 s. Therefore, the reaction rate for the simulation of glucose conversion would be calculated as follows:

$$
-r=10^{3.09 \pm 0.26} \exp \left(\frac{-67.6 \pm 3.9}{R T}\right)[\text { glucose }]
$$

where, $\mathrm{r}(\mathrm{mol} / \mathrm{L} \cdot \mathrm{s}), \mathrm{E}_{\mathrm{a}}(\mathrm{kJ} / \mathrm{mol})$, Temperature $(\mathrm{K})$ and [glucose] is $(\mathrm{mol} / \mathrm{L})$. 
For the validation of the experimental data, the reactor was considered to be a plug flow reactor, since this reactor type has a L/D ratio $>>100$ and the flow is turbulent in most of the experiments (Reynolds number is greater than 2200) [59]. In fact, the Reynolds number reached just 1708 in the last of the experiments, where a catalyst was used, and the residence time was $10 \mathrm{~s}$. Nevertheless, the plug flow reactor assumption was held even for the lowest Reynolds number (1708) that was obtained at $535^{\circ} \mathrm{C}$ and with a $1.3 \mathrm{~mL} / \mathrm{min}$ flow, since the surface reactions that took place were negligible [60]. Cutler et al. [61] reported that a number of effects should also be taken into account for the idealization of a tubular flow reactor as plug flow. This approach requires that seven time constants associated to the reactor and its operating conditions are previously determined. Such time constants are then used to verify a number of criteria. In their experimental reactor, Cutler et al. did not manage to meet the criterion related to radial diffusion nor the one associated with surface reactions and, according to their report, such criteria are not relevant when surface reactions are not significant. It could, therefore, assume that our reactor can be idealized as a plug flow reactor under the given test conditions.

Equation (12) was validated according to the data from the experiments that had been carried out at residence times of $10-50 \mathrm{~s}$, and it is a simplified expression of the overall gasification reaction (Equation (11)). In a first step, only the results from the tests that correspond to gasification with a maximum $n$ value of 0.4 and for $10 \mathrm{~s}$ residence time have been represented in Figure 8. It can be seen from this figure that the experiments that present a satisfactory agreement between the model and the actual experimental data are those with optimal oxygen coefficient values (around $\mathrm{n}=0.4)$. Thus, the gasification process can be validated according to this simplified reaction rate expression (Equation (12)). However, there are two different groups of experiments that present some disagreement, as can be seen in Figure 8. There are two pathways in partial oxidation SCWG processes: gasification and oxidation, two competing reactions [15]. In experiments where oxygen levels are low (around $\mathrm{n}<0.4$ ), the steam reforming reaction is predominant over the oxidation one, so that hydrogen yields are enhanced when oxygen coefficients are higher. Therefore, when the oxygen coefficient is roughly lower than 0.4 , the hydrogen yield predicted by the equation is generally higher than the actual yield obtained from the experiment. This is probably due to a shortage in oxygen supply, and in turn, of energy to adequately support hydrogen production. On the contrary, higher experimental gasification efficiency than the predicted ones are obtained when the lowest initial concentration rates are fed $(0.06$ and $0.1 \mathrm{~g}$ cellulose/L), as can be seen in Figure 8 . These disagreements could be explained by the enhancement of hydrolysis and water-gas shift reactions that takes place when an initial biomass with a low concentration is fed, which, as mentioned above, results in greater hydrogen yields.

The predicted gasification efficiency compare with the experimental data from all experiments are shown in Figure 9. As can be seen, the closest agreement between both sets of data is observed when the experiments are carried out with an oxygen coefficient $n=0.4$. However, some of the data presented considerable discrepancies. The two groups of experiments that presented noticeable disagreements are the same ones that are present in Figure 8. A higher predicted gasification efficiency than the experimental was obtained from the experiments where the oxygen coefficient was different from $\mathrm{n}=0.4$. In those experiments where the oxygen coefficient was close to or greater than 0.5 , the oxidation reactions became predominant and, as a consequence of this, hydrogen yields were smaller. To sum up, when the oxygen coefficient has its optimal value (around $n=0.4$ ) the gasification process can be validated according to this simplified reaction rate expression. Probably, although the authors in this work [32] do not supply any particular amounts of oxygen into the system, there may be some oxygen in the system that has not been quantified and it can produce an effect similar to that obtained in this work. On the other hand, as can be seen in Figure 9, all the experiments where a low initial concentration of biomass and a catalyst were used reached actual experimental gasification efficiency levels above the predicted ones. These disagreements could be attributed to the positive effect of a low initial biomass concentration, which, combined with the positive effect of an alkali catalysts, particularly especially $\mathrm{KOH}$ and $\mathrm{K}_{2} \mathrm{CO}_{3}$, enhances water-gas shift reactions [48] and results in larger hydrogen yields. 


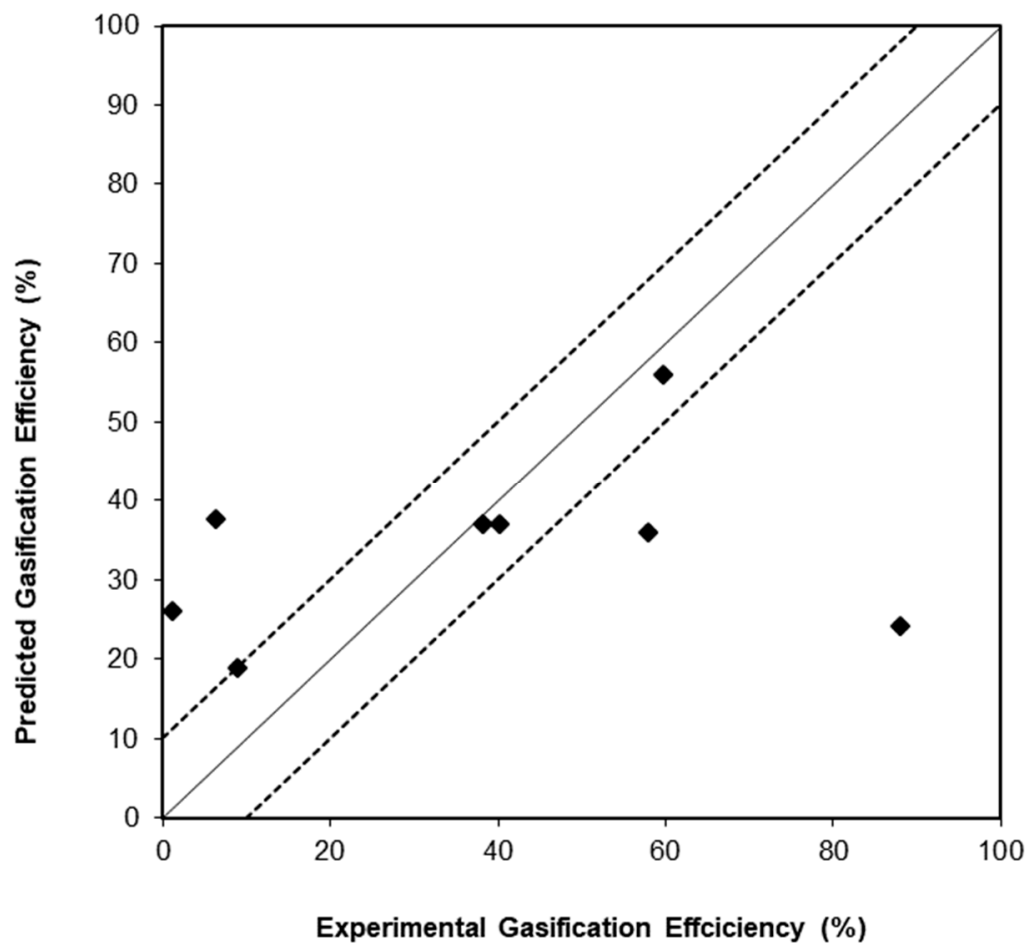

Figure 8. Predicted vs. experimental gasification efficiency of the SCWG of cellulose for 10-s residence time runs.

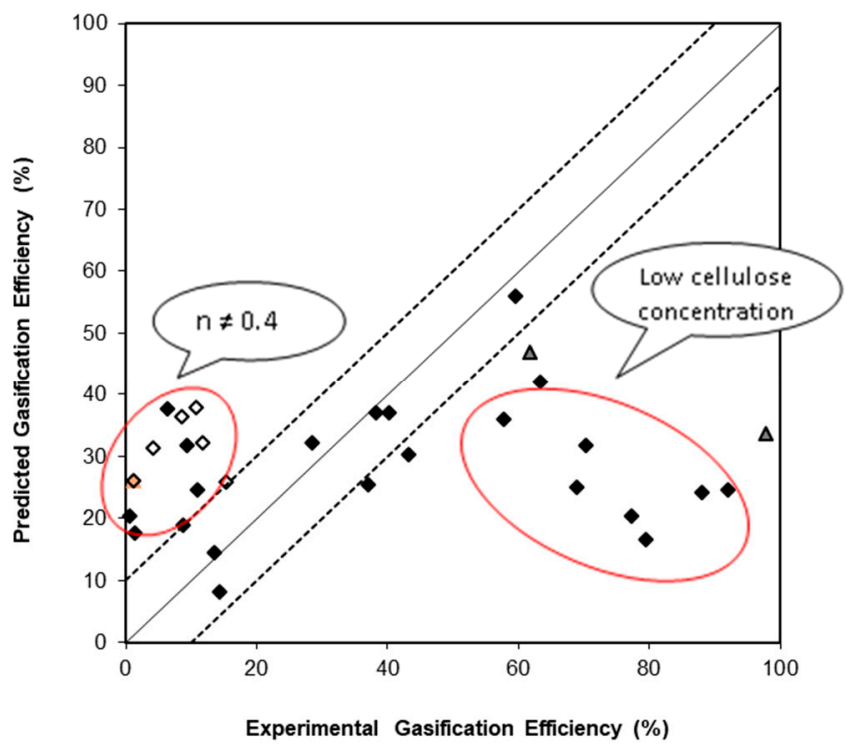

Figure 9. Predicted vs. experimental gasification efficiency of the SCWG of cellulose. Experiments with $\mathrm{n}<0.4(\diamond), \mathrm{n}>0.4(\diamond)$ and experiments with $\mathrm{KOH}(\boldsymbol{\Delta})$.

Therefore, in this way, Equation (12) is a simple and valid representation of the experimental data registered when cellulose the SCWG process is carried out on an initial organic concentration in the range $0.3-0.6 \mathrm{~g}$ cellulose/ $\mathrm{L}$ and for $\mathrm{n}=0.4$ oxygen coefficient. However, any variation from these ideal conditions has a remarkable effect on other chemical reactions, such as oxidation, which takes a more predominant role over the whole process. This illustrates how the data obtained from this equation can only be used as a reference when such ideal conditions are met and, thus any other calculations of the changes in hydrogen yields efficiency associated to the variations of any of the relevant parameters cannot be relied on. Therefore, a deeper kinetic study to elaborate on a model of the different reactions 
kinetics under varying conditions with regards to oxidant coefficient and feed concentration is still to be completed.

\section{Conclusions}

Supercritical water gasification by means of a continuous reactor has been applied to the production of hydrogen from cellulose, and the effects from each on the main parameters have been determined. The parameters studied were temperature, cellulose concentration, and the presence of $\mathrm{KOH}$ over three different residence times $(6,8$ and $10 \mathrm{~s})$, while pressure remained constant at 250 bar. It was observed that hydrogen yields increased with temperature and an efficiency level of around $100 \%$ was reached at $560^{\circ} \mathrm{C}$ in 6-s residence time runs. On the other hand, it was also observed that feed concentration rates have the opposite effect; thus, hydrogen yields fall when higher biomass concentration rates are fed into the system. Furthermore, the best results were obtained when $\mathrm{KOH}$ was used as a catalyst. In fact, hydrogen gasification efficiency reached values of up to $112.74 \%$ with a Lower Heating Value (LHV) of the gas products up to $17393.8 \mathrm{~kJ} / \mathrm{Nm}^{3}$ when the conditions were $535^{\circ} \mathrm{C}, 0.3 \mathrm{~g}$ cellulose $/ \mathrm{L}$ concentration rate, 6-s residence time and $\mathrm{n}=0.4$ oxygen coefficient. A simplified mathematical expression has been used that allows to calculate the gasification efficiency of SCWG processes applied to cellulose under these optimal conditions. These results demonstrate the effectiveness of the process and present an advance in the knowledge of this technology for the perspective of the application of SCWG for the processing of lignocellulosic biomass.

Author Contributions: Formal analysis, J.S.-O. and B.A.-D.; funding acquisition, E.J.M.d.1.O.; investigation, M.B.G.-J. and J.R.P.; project administration, E.J.M.d.I.O. and B.A.-D.; resources, B.A.-D.; supervision, J.R.P., J.S.-O., E.J.M.d.1.O. and B.A.-D.; writing-original draft, M.B.G.-J.; writing-review \& editing, M.B.G.-J., J.R.P. and J.S.-O. All authors have read and agreed to the published version of the manuscript.

Funding: Co-financed by project FEDER-UCA18-108297 mentioned in acknowledgements.

Acknowledgments: This work has been co-financed by the 2014-2020 ERDF Operational Programme and by the Department of Economy, Knowledge, Business and University of the Regional Government of Andalusia. Project reference: FEDER-UCA18-108297. Moreover, we would like to thank the Regional Government Junta de Andalucía (project P11-RNM-07048) for its financial support and the Agro food International Excellence Campus CeiA3 for its financial support through a Postdoctoral grant.

Conflicts of Interest: The authors declare no conflict of interest.

\section{References}

1. Hasler, P.; Nussbaumer, T. Gas cleaning for IC engine applications from fixed bed biomass gasification. Biomass Bioenergy 1999, 16, 385-395. [CrossRef]

2. Yoshida, Y.; Dowaki, K.; Matsumura, Y.; Matsuhashi, R.; Li, D.; Ishitani, H.; Komiyama, H. Comprehensive comparison of efficiency and $\mathrm{CO}_{2}$ emissions between biomass energy conversion technologies-Position of supercritical water gasification in biomass technologies. Biomass Bioenergy 2003, 25, 257-272. [CrossRef]

3. García-Jarana, M.B.; Sánchez-Oneto, J.; Portela, J.R.; Martínez de la Ossa, E.J. Supercritical water gasification of organic wastes for energy generation. In Supercritical Fluid Technology for Energy and Environmental Applications; Elsevier B.V.: Amsterdam, The Netherlands, 2014; pp. 191-200.

4. Holgate, H.R. Oxidation Chemistry and Kinetics in Supercritical Water: Hydrogen, Carbon Monoxide, and Glucose. Ph.D. Thesis, Massachusetts Institute of Technology, Cambridge, MA, USA, 1993.

5. Vostrikov, A.A.; Fedyaeva, O.N.; Shishkin, A.V.; Sokol, M.Y.; Kolobov, F.I.; Kolobov, V.I. Partial and complete methane oxidation in supercritical water. J. Eng. Thermophys. 2016, 25, 474-484. [CrossRef]

6. Susanti, R.F.; Dianningrum, L.W.; Yum, T.; Kim, Y.; Lee, B.G.; Kim, J. High-Yield hydrogen production from glucose by supercritical water gasification without added catalyst. Int. J. Hydrog. Energy 2012, 37, 11677-11690. [CrossRef]

7. Seif, S.; Tavakoli, O.; Fatemi, S.; Bahmanyar, H. Subcritical water gasification of beet-based distillery wastewater for hydrogen production. J. Supercrit. Fluids 2015, 104, 212-220. [CrossRef]

8. Resende, F.L.P.; Neff, M.E.; Savage, P.E. Noncatalytic gasification of cellulose in supercritical water. Energy Fuels 2007, 21, 3637-3643. [CrossRef] 
9. Zhu, C.; Guo, L.; Jin, H.; Huang, J.; Li, S.; Lian, X. Effects of reaction time and catalyst on gasification of glucose in supercritical water: Detailed reaction pathway and mechanisms. Int. J. Hydrog. Energy 2016, 41, 6630-6639. [CrossRef]

10. Ding, N.; Azargohar, R.; Dalai, A.K.; Kozinski, J.A. Catalytic gasification of cellulose and pinewood to $\mathrm{H}_{2}$ in supercritical water. Fuel 2014, 118, 416-425. [CrossRef]

11. Yakaboylu, O.; Harinck, J.; Smit, K.G.; de Jong, W. Supercritical water gasification of biomass: A literature and technology overview. Energies 2015, 8, 859-894. [CrossRef]

12. Resende, F.L.P.; Fraley, S.A.; Berger, M.J.; Savage, P.E. Noncatalytic gasification of lignin in supercritical water. Energy Fuels 2008, 22, 1328-1334. [CrossRef]

13. Nanda, S.; Reddy, S.N.; Hunter, H.N.; Dalai, A.K.; Kozinski, J.A. Supercritical water gasification of fructose as a model compound for waste fruits and vegetables. J. Supercrit. Fluids 2015, 104, 112-121. [CrossRef]

14. Antal, M.J., Jr.; Allen, S.G.; Schulman, D.; Xu, X.; Divilio, R.J. Biomass gasification in supercritical water. Ind. Eng. Chem. Res. 2000, 39, 4040-4053. [CrossRef]

15. García Jarana, M.B.; Sánchez-Oneto, J.; Portela, J.R.; Martínez de la Ossa, E.J. Supercritical water gasification of industrial organic wastes. J. Supercrit. Fluids 2008, 46, 329-334. [CrossRef]

16. Zhai, Y.; Wang, C.; Chen, H.; Li, C.; Zeng, G.; Pang, D.; Lu, P. Digested sewage sludge gasification in supercritical water. Waste Manag. Res. 2013, 31, 393-400. [CrossRef] [PubMed]

17. Kıpçak, E.; Sögüt, O.Ö.; Akgün, M. Hydrothermal gasification of olive mill wastewater as a biomass source in supercritical water. J. Supercrit. Fluids 2011, 57, 50-57. [CrossRef]

18. Matsumura, Y.; Minowa, T.; Potic, B.; Kersten, S.; Prins, W.; Vanswaaij, W.; Van De Beld, B.; Elliott, D.C.; Neuenschwander, G.; Kruse, A. Biomass gasification in near- and super-critical water: Status and prospects. Biomass Bioenergy 2005, 29, 269-292. [CrossRef]

19. Watanabe, M.; Mochiduki, M.; Sawamoto, S.; Adschiri, T.; Arai, K. Partial oxidation of n-hexadecane and polyethylene in supercritical water. J. Supercrit. Fluids 2001, 20, 257-266. [CrossRef]

20. Armbruster, U.; Martin, A.; Krepel, A. Partial oxidation of propane in sub- and supercritical water. J. Supercrit. Fluids 2001, 21, 233-243. [CrossRef]

21. Kruse, A.; Henningsen, T.; Sinag, A.; Pfeiffer, J. Biomass gasification in supercritical water: Influence of the dry matter content and the formation of phenols. Ind. Eng. Chem. Res. 2003, 42, 3711-3717. [CrossRef]

22. Portela, J.R.; Lopez, J.; Nebot, E.; Martínez de la Ossa, E.J. Elimination of cutting oil wastes by promoted hydrothermal oxidation. J. Hazard. Mater. 2001, 88, 95-106. [CrossRef]

23. Yoshida, T.; Oshima, Y. Partial oxidative and catalytic biomass gasification in supercritical water: A promising flow reactor system. Ind. Eng. Chem. Res. 2004, 43, 4097-4104. [CrossRef]

24. Wantanabe, M.; Inomata, H.; Osada, M.; Sato, T.; Adschin, T.; Arai, K. Catalytic effects of $\mathrm{NaOH}$ and $\mathrm{ZrO} 2$ for partial oxidative gasification of n-hexadecane and lignin in supercritical water. Fuel 2003, 82, 545-552. [CrossRef]

25. Jin, H.; Lu, Y.; Guo, L.; Cao, C.; Zhang, X. Hydrogen production by partial oxidative gasification of biomass and its model compounds in supercritical water. Int. J. Hydrogen Energy 2010, 35, 3001-3010. [CrossRef]

26. Johanson, N.W.; Spritzer, M.H.; Hong, G.T.; Rickman, W.S. Supercritical water partial oxidation. In Proceedings of the 2001 U.S. DOE Hydrogen Program Review, NREL/CP-570-30535, Baltimore, MD, USA, 17-19 April 2001.

27. Safari, F.; Tavasoli, A.; Ataei, A.; Choi, J.K. Hydrogen and syngas production from gasification of lignocellulosic biomass in supercritical water media. Int. J. Recycl. Org. Waste Agric. 2015, 4, 121-125. [CrossRef]

28. Yanik, J.; Ebale, A.; Kruse, A.; Saglam, M.; Yuksel, M. Biomass gasification in supercritical water: Part 1. effect of the nature of biomass. Fuel 2007, 86, 2410-2415. [CrossRef]

29. Xu, X.D.; Antal, M.J. Gasification of sewage sludge and other biomass for hydrogen production in supercritical water. Environ. Prog. 1998, 17, 215-220. [CrossRef]

30. Lu, Y.J.; Guo, L.J.; Ji, C.M.; Zhang, X.M.; Hao, X.H.; Yan, Q.H. Hydrogen production by biomass gasification in supercritical water: A parametric study. Int. J. Hydrogen Energy 2006, 31, 822-831. [CrossRef]

31. Williams, P.T.; Onwudili, J. Composition of products from the supercritical water gasification of glucose: A model biomass compound. Ind. Eng. Chem. Res. 2005, 44, 8739-8749. [CrossRef]

32. Lee, I.; Kim, M.; Ihm, S.K. Gasification of glucose in supercritical water. Ind. Eng. Chem. Res. 2002, 41, 1182-1188. [CrossRef] 
33. Hao, X.H.; Guo, L.J.; Mao, X.A.; Zhang, X.M.; Chen, X.J. Hydrogen production from glucose used as a model compound of biomass gasified in supercritical water. Int. J. Hydrogen Energy 2003, 28, 55-64. [CrossRef]

34. Reddy, S.N.; Nanda, S.; Dalai, A.K.; Kozinski, J.A. Supercritical water gasification of biomass for hydrogen production. Int. J. Hydrogen Energy 2014, 39, 6912-6926. [CrossRef]

35. Guo, Y.; Wang, S.Z.; Xu, D.H.; Gong, Y.M.; Ma, H.H.; Tang, X.Y. Review of catalytic supercritical water gasification for hydrogen production from biomass. Renew. Sustain. Energy Rev. 2010, 14, 334-343. [CrossRef]

36. Ferreira-Pinto, L.; Feirhrmann, A.C.; Corazza, M.L.; Camargo Fernandes-Machado, N.R.; dos Reis Coimbra, J.S.; Saldaña, M.D.A.; Cardozo-Filho, L. Hydrogen production and TOC Reduction from gasification of lactose by supercritical water. Int. J. Hydrogen Energy 2015, 40, 12162-12168. [CrossRef]

37. Onwudili, J.A.; Williams, P.T. Role of sodium hydroxide in the production of hydrogen gas from the hydrothermal gasification of biomass. Int. J. Hydrogen Energy 2009, 34, 5645-5656. [CrossRef]

38. Casademont, P.; Cardozo-Filho, L.; Meurer, E.; Sánchez-Oneto, J.; Portela, J.R. Gasification of olive oil mill waste by supercritical water in a continuous reactor. J. Supercrit. Fluids 2018, 142, 10-21. [CrossRef]

39. Casademont, P.; Sánchez-Oneto, J.; Scandelai, A.P.J.; Cardozo-Filho, L.; Portela, J.R. Hydrogen production by supercritical water gasification of black liquor: Use of high temperatures and short residence times in a continuous reactor. J. Supercrit. Fluids 2020, 159, 104772. [CrossRef]

40. Williams, P.T.; Onwudili, J. Subcritical and supercritical water gasification of cellulose, starch, glucose, and biomass waste. Energy Fuels 2006, 20, 1259-1265. [CrossRef]

41. Basu, P. Hydrothermal gasification of biomass. In Biomass Gasification and Pyrolysis Practical Design and Theory; Elsevier B.V.: Amsterdam, The Netherlands, 2010; pp. 229-267.

42. Hao, X.H.; Guo, L.J.; Zhang, X.M.; Guan, Y. Hydrogen production from catalytic gasification of cellulose in supercritical water. Chem. Eng. J. 2005, 110, 57-65. [CrossRef]

43. Resende, F.L.P.; Savage, P.E. Expanded and updated results for supercritical water gasification of cellulose and lignin in metal-free reactors. Energy Fuels 2009, 23, 6213-6221. [CrossRef]

44. Yoshida, T.; Oshima, Y.; Matsumura, Y. Gasification of biomass model compounds and real biomass in supercritical water. Biomass Bioenergy 2004, 26, 71-78. [CrossRef]

45. Yoshida, T.; Matsumura, Y. Gasification of cellulose, xylan, and lignin mixtures in supercritical water. Ind. Eng. Chem. Res. 2001, 40, 5469-5474. [CrossRef]

46. Calzavara, Y.; Joussot-Dubien, C.; Boissonnet, G.; Sarrade, S. Evaluation of biomass gasification in supercritical water process for hydrogen production. Energy Convers. Manag. 2005, 46, 615-631. [CrossRef]

47. Nanda, S.; Isen, J.; Dalai, A.K.; Kozinski, J.A. Gasification of fruit wastes and agro-food residues in supercritical water. Energy Convers. Manag. 2016, 110, 296-306. [CrossRef]

48. Okolie, J.A.; Rana, R.; Nanda, S.; Dalai, A.K.; Kozinski, J.A. Supercritical water gasification of biomass: A state of-the-art review of process parameters, reaction mechanisms and catalysis. Sustain. Energy Fuels 2019, 3, 578-598. [CrossRef]

49. Guan, Q.Q.; Wei, C.H.; Shi, H.S.; Wu, C.F.; Chai, X.S. Partial oxidative gasification of phenol for hydrogen in supercritical water. Appl. Energy 2011, 88, 2612-2616. [CrossRef]

50. Wang, Y.; Wang, S.; Zhao, G.; Guo, Y.; Guo, Y. Hydrogen production by partial oxidation gasification of a phenol, naphthalene, and acetic acid mixture in supercritical water. Int. J. Hydrogen Energy 2016, 41, 2238-2246. [CrossRef]

51. Nanda, S.; Reddy, S.N.; Hunter, H.N.; Butler, I.S.; Kozinski, J.A. Supercritical water gasification of lactose as a model compound for valorization of dairy industry effluents. Ind. Eng. Chem. Res. 2015, 54, 9296-9306. [CrossRef]

52. Kruse, A.; Gawlik, A. Biomass conversion in water at $330-410{ }^{\circ} \mathrm{C}$ and $30-50 \mathrm{MPa}$. Identification of key compounds for indicating different chemical reaction pathways. Ind. Eng. Chem. Res. 2003, 42, 267-279.

53. Guan, Q.Q.; Wei, C.H.; Chai, X.S. Pathways and kinetics of partial oxidation of phenol in supercritical water. Chem. Eng. J. 2011, 175, 201-206. [CrossRef]

54. Lv, P.M.; Xiong, Z.H.; Chang, J.; Wu, C.Z.; Chen, Y.; Zhu, J.X. An experimental study on biomass air-steam gasification in a fluidized bed. Bioresour. Technol. 2004, 95, 95-101. [CrossRef]

55. Rodriguez Correa, C.; Kruse, A. Supercritical water gasification of biomass for hydrogen production-Review. J. Supercrit Fluids 2018, 133, 573-590. [CrossRef]

56. Kruse, A. Supercritical water gasification. Biofuels Bioprod. Biorefining 2008, 2, 415-437. [CrossRef] 
57. Xu, D.; Wang, S.; Hu, X.; Chen, C.; Zhang, Q.; Gong, Y. Catalytic gasification of glycine and glycerol in supercritical water. Int. J. Hydrogen Energy 2009, 34, 5357-5364. [CrossRef]

58. Tushar, M.S.H.K.; Dutta, A.; Xu, C. Simulation and kinetic modeling of supercritical water gasification of biomass. Int. J. Hydrogen Energy 2015, 40, 4481-4493. [CrossRef]

59. Chkoundali, S.; Alaya, S.; Launay, J.C.; Gabsi, S.; Cansell, F. Hydrothermal oxidation of olive oil mill wastewater with multi-injection of oxygen simulation and experimental data. Environ. Eng. Sci. 2008, 25, 173-180. [CrossRef]

60. Li, L.; Portela, J.R.; Vallejo, D.; Gloyna, E.F. Oxidation and hydrolysis of lactic acid in near-critical water. Ind. Eng. Chem. Res. 1999, 38, 2599-2606. [CrossRef]

61. Cutler, A.H.; Antal, M.J., Jr.; Jones, M., Jr. A critical evaluation of the plug-flow idealization of tubular-flow reactor data. Ind. Eng. Chem. Res. 1988, 27, 691-697. [CrossRef]

(C) 2020 by the authors. Licensee MDPI, Basel, Switzerland. This article is an open access article distributed under the terms and conditions of the Creative Commons Attribution (CC BY) license (http://creativecommons.org/licenses/by/4.0/). 